\title{
EXPERIMENTAL MODELS OF HEPATECTOMY AND LIVER REGENERATION USING NEWBORN AND WEANING RATS
}

\author{
Ana Cristina Aoun Tannuri, Uenis Tannuri, Maria Cecília Coelho, Neide \\ Aparecida dos Santos e Evandro Sobroza de Mello
}

\begin{abstract}
Tannuri ACA, Tannuri U, Coelho MC, dos Santos NA, Mello ES. Experimental models of hepatectomy and liver regeneration using newborn and weaning rats. Clinics. 2007;62(6):757-62.
\end{abstract}

OBJECTIVES: Liver regeneration is a complex process that has not been completely elucidated. The model most frequently used to study this phenomenon is $70 \%$ hepatectomy in adult rats; however, no papers have examined this effect in developing animals. The aims of the present study were: 1) to standardize two models of partial hepatectomy and liver regeneration in newborn suckling and weaning rats, and 2) to study the evolution of remnant liver weight and histological changes of hepatic parenchyma on the days that follow partial hepatectomy.

METHODS: Fifty newborn and forty-four weaning rats underwent $70 \%$ hepatectomy. After a midline incision, compression on both sides of the upper abdomen was performed to exteriorize the right medial, left medial and left lateral hepatic lobes, which were tied inferiorly and resected en bloc. The animals were sacrificed on days 0 (just after hepatectomy), 1, 2, 3, 4 and 7 after the operation. Body and liver weight were determined, and hepatic parenchyma was submitted to histological analysis.

RESULTS: Mortality rates of the newborn and weaning groups were $30 \%$ and $0 \%$, respectively. There was a significant decrease in liver mass soon after partial hepatectomy, which completely recovered on the seventh day in both groups. Newborn rat regenerating liver showed marked steatosis on the second day. In the weaning rat liver, mitotic figures were observed earlier, and their amount was greater than in the newborn. CONCLUSIONS. Suckling and weaning rat models of partial hepatectomy are feasible and can be used for studies of liver regeneration. Although similar, the process of hepatic regeneration in developing animals is different from adults.

KEYWORDS: Liver regeneration. Animal models. Hepatectomy. Newborn animals. Rat.

\section{INTRODUCTION}

The liver has significant regenerative capacity after injury. Even after major insult, such as extensive surgical resection, its function usually recovers within a couple of weeks. This is accomplished through complex mechanisms that have not been fully elucidated. ${ }^{1}$

Studies of liver regeneration in humans are difficult because of the heterogeneous etiology of liver lesions that pre-

Pediatric Surgery Laboratory (LIM 30) and Liver Function Research Laboratory (LIM-14), Faculdade de Medicina, Universidade de São Paulo/ SP, Brazil.

Email: cristannuri@uol.com.br

Received for publication on June 28, 2007

Accepted for publication on August 24, 2007 cede regeneration. ${ }^{2}$ For these reasons, investigation of liver regeneration in standardized experimental models seems to be more useful than clinical studies. Regeneration models may be in vitro and in vivo. Cultured hepatocytes (in vitro model) have very different physiological responses relative to in vivo models, and it has been increasingly recognized that non-parenchymal cells may play an important role in in vivo regeneration because their interaction with hepatocytes is implicated in all physiological responses of the liver. ${ }^{3}$

In 1931, Higgins and Anderson published a model of $70 \%$ hepatectomy in adult rats ${ }^{4}$, which has been employed heavily in investigations of hepatic regeneration. ${ }^{5,6}$ Small animals, such as mice and rats, are useful because they are easy to manage and represent minimal logistical, financial 
or ethical problems ${ }^{2}$. However, physiological differences, such as having a faster metabolism relative to humans, must be considered. Under normal circumstances, the human liver initiates regeneration within 3 days and reaches its original size by 3-6 months. ${ }^{1}$ In rats, the interval between partial hepatectomy and initiation of DNA synthesis in hepatocytes is 10 to 12 hours and peaks at about 24 hours. $^{7}$ Liver weight is completely recovered by the seventh day. Histological examination reveals slight hypertrophy of both cytoplasmic bodies and nuclei. Mitosis begins by the end of the first day, and cell division is completed on the second and third days. ${ }^{4}$

In normal individuals, liver regeneration can be affected by a number of factors that jeopardize the quality and end result of the process. Aging is one of these factors. BiondoSimões et al. observed that hepatocyte replication is delayed in the livers of older animals. ${ }^{8}$ Therefore, the phenomena involved in the liver regeneration of developing animals are characterized by different intensity and quality, as compared to the adult animals.

Understanding hepatic regeneration in children has become more important lately due to partial liver transplantations that have been performed with increasing frequency in this age group of patients..$^{9-11}$ Although the Higgins and Anderson model has been used extensively, there are no studies of hepatectomy and liver regeneration in growing animal models.

The aims of the present experimental study were: 1) to standardize two animal models of partial hepatectomy $(\mathrm{PH})$ and liver regeneration using newborn suckling and weaning rats, and 2) to study the evolution of remnant liver weight and histological changes of regenerating hepatic parenchyma on the days following partial hepatectomy.

\section{MATERIAL AND METHODS}

Animals

Fifty newborn suckling rats (age 5-7 days, weight 6-10 g) and forty-four weaning rats (age 21-23 days, weight 30$50 \mathrm{~g}$ ) were operated upon. All animals received care according to the criteria outlined in the "Guide for Care and Use of Laboratory Animals" prepared by the National Academy of Sciences; this study protocol and the anesthetic procedures were approved by the Animal Ethic Committee of University of São Paulo Medical School.

The suckling rats were maintained with their mothers in stainless steel cages. The weaning rats were kept on standard laboratory diet and tap water ad libitum throughout the experiment.

\section{Creation of experimental models}

All the animals were operated on by the same two surgeons (UT and ACAT) wearing surgical telescopes (magnification 3.5X) and microsurgical instruments. The surgical procedures were performed under sterile conditions between 9:00 AM and 10:00 AM, due to the circadian rhythm of liver regeneration. Ether-soaked gauze was kept near the animals' nose to induce and maintain anesthesia. This type of anesthesia is considered safe for small animals subjected to short surgical procedures. Following a $1 \mathrm{~cm}$ midline incision, the upper abdomen and lateral lower portions of both hemi-thoraces were compressed to exteriorize the liver. Consequently, adequate mobilization and exposure of the liver could be attained without dividing the ligaments of the right and left lobes (Fig. 1). The liver parenchyma could not be touched because of the dangers of injuring the viscera and bleeding. A 2-0 cotton thread knot, surrounding the hilum and also the hepatic vein, was tied and the right medial, left medial and left lateral lobes were resected en bloc (Fig. 2 and 3). Because the rat liver is lobulated, the hilum of these lobes could be safely ligated without involving the vasculature of the remnant lobes. The abdomen was closed with a single-layer running suture using 6-0 prolene. Following surgery, the suckling animals were returned to their mothers, and the weaning animals were fed regular diets and water ad libitum. The animals were sacrificed 0 (just after the hepatectomy), 1, 2, 3, 4 or 7 days after the operation, under ether anesthesia, and the body weights were determined. A midline single abdominal and thoracic incision was performed to harvest the remnant liver lobes, which were then weighed and fixed in $10 \%$ neutral buffered formalin for routine histology. Groups of normal non-

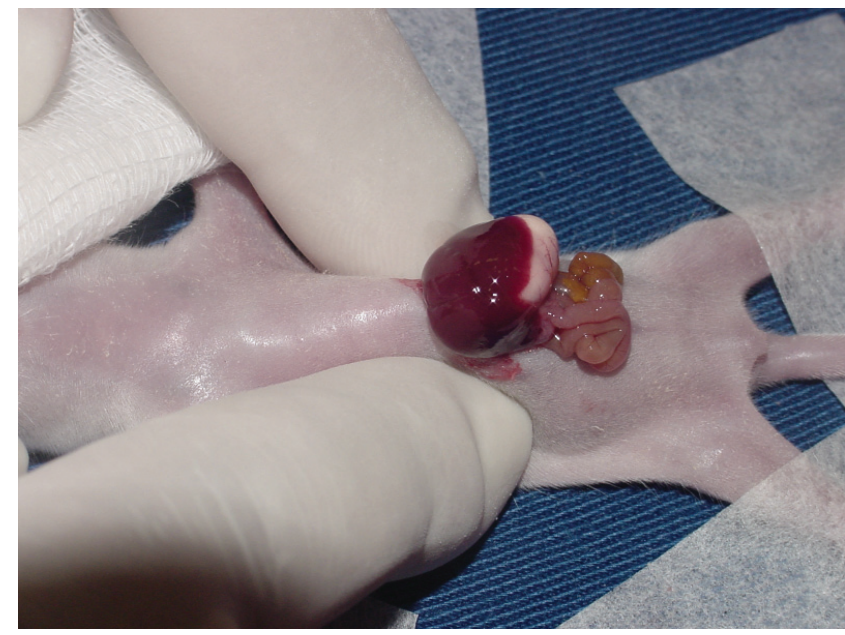

Figure 1 - Partial hepatectomy in newborn rat: liver, stomach and guts exteriorized by compression of the upper abdomen and the lateral inferior portions of the hemithorax bilaterally. 


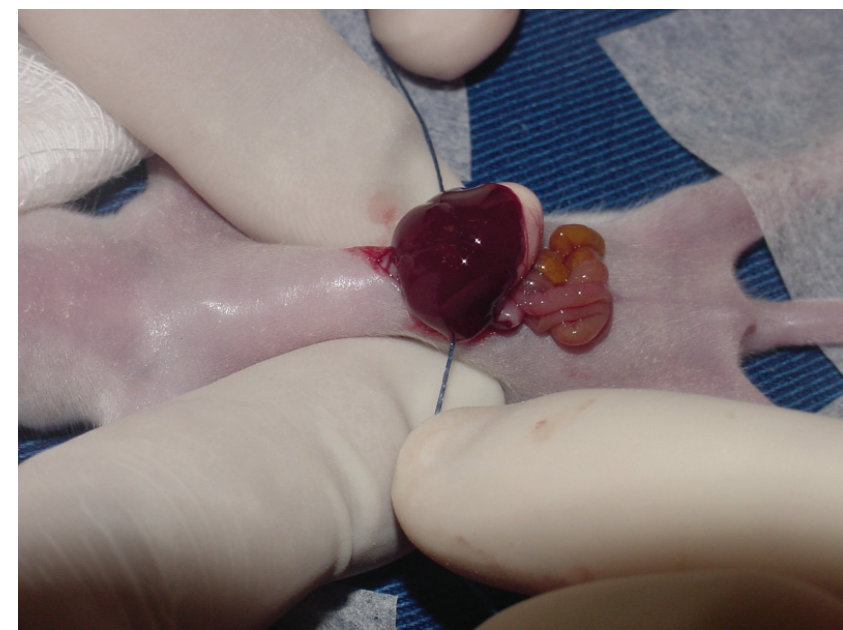

Figure 2 - A cotton ligature was passed between the liver and stomach.

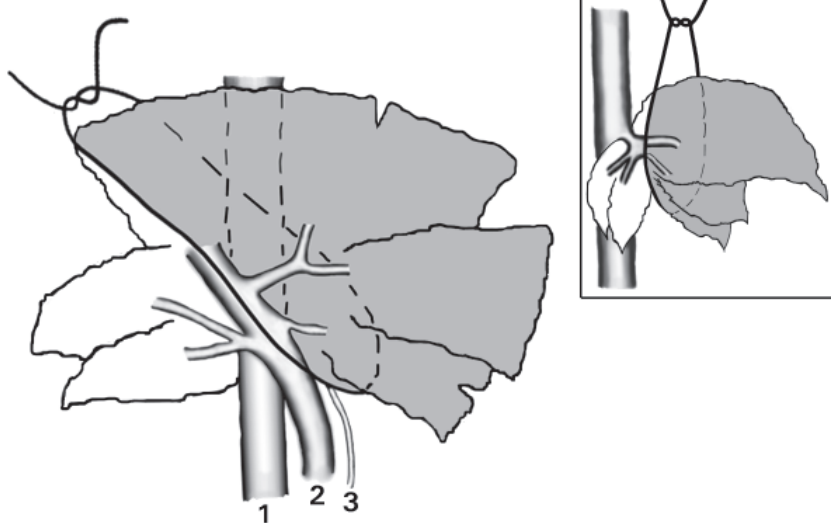

Figure 3 - Schematic illustration of the parenchymal resection; detailed lateral view. The dark area indicates the parenchyma to be resected.

operated weaning and suckling animals served as controls.

\section{Histological analysis}

Qualitative histological examination was performed in 4- $\mu \mathrm{m}$ thick sections of all liver samples (x 300, 600 and 1500). Lobular architecture, as well as presence of mitotic figures, apoptotic bodies and steatosis, was evaluated.

\section{Statistical analysis}

The mortality rates of the groups were expressed as percentages and were compared using the Fisher test. The other results were expressed as means \pm SD. For statistical purposes, ANOVA and Bonferroni tests were employed (liver weights/body weight ratios presented a parametric distribution). $\mathrm{P}<0.05$ was considered significant.

\section{RESULTS}

\section{Mortality rates}

Twelve deaths occurred in the newborn group (24\%). The causes were anesthetic complications, cut surface bleeding and maternal cannibalism. There were no deaths in the weaning group. The comparison of mortality rates of groups demonstrated a significant difference $(P=0.003)$.

\section{Liver weight/body weight ratios following partial hepatectomy}

To evaluate growth of the remnant liver following $\mathrm{PH}$, the liver weight/body weight ratio was calculated on 0,1 , 2, 3, 4 and 7 days after hepatectomy (Fig. 4).

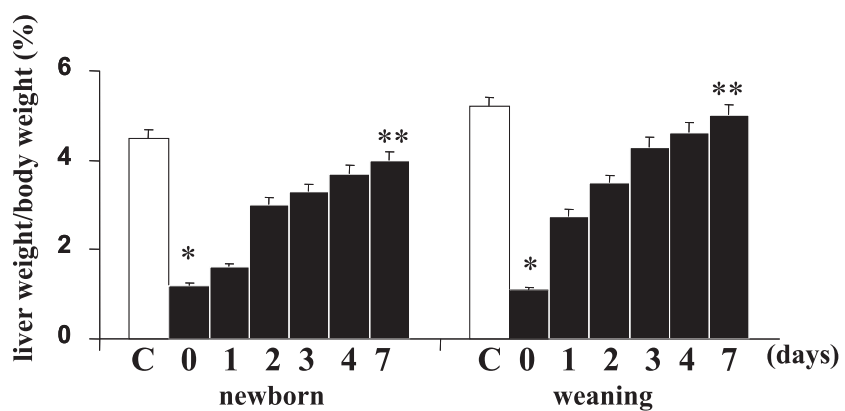

Figure 4 - Changes in the ratio of the remnant liver wet weight relative to body weight at varying timepoints after hepatectomy (for each group, $\mathrm{n}=$ 6-8 animals). Values are means \pm SEM. ( ${ }^{*}$ significant; ${ }^{* *}$ nonsignificant in comparison to $\mathrm{C}-$ control group).

There was a significant decrease in liver mass just after $\mathrm{PH}$ ( $\mathrm{P}<0.0001$ for both newborn and weaning groups). On the seventh day, the liver weight was completely recovered in both groups $(\mathrm{P}>0.05)$.

\section{Pathological analysis}

Liver parenchyma of control newborn rats showed a typical sinusoidal architecture and several extramedullary hematopoietic foci (Fig. 5-1). Mitotic figures and apoptotic bodies were absent.

On the first day after PH, hepatocyte nuclei of suckling animals were increased in size, with vesicular bodies and prominent nucleoli, but no mitosis was detected. On the second day, entire lobules were characterized by macrovesicular steatosis, which markedly decreased on the following day, when a few mitotic figures could be observed. Apoptotic bodies were rarely seen. On the fourth day, hepatocyte mitosis was still observed, and fatty infiltration was further diminished. Finally, on the seventh day 
after $\mathrm{PH}$, the histological aspect of the liver was similar to controls (Fig. 5-2 to 6).
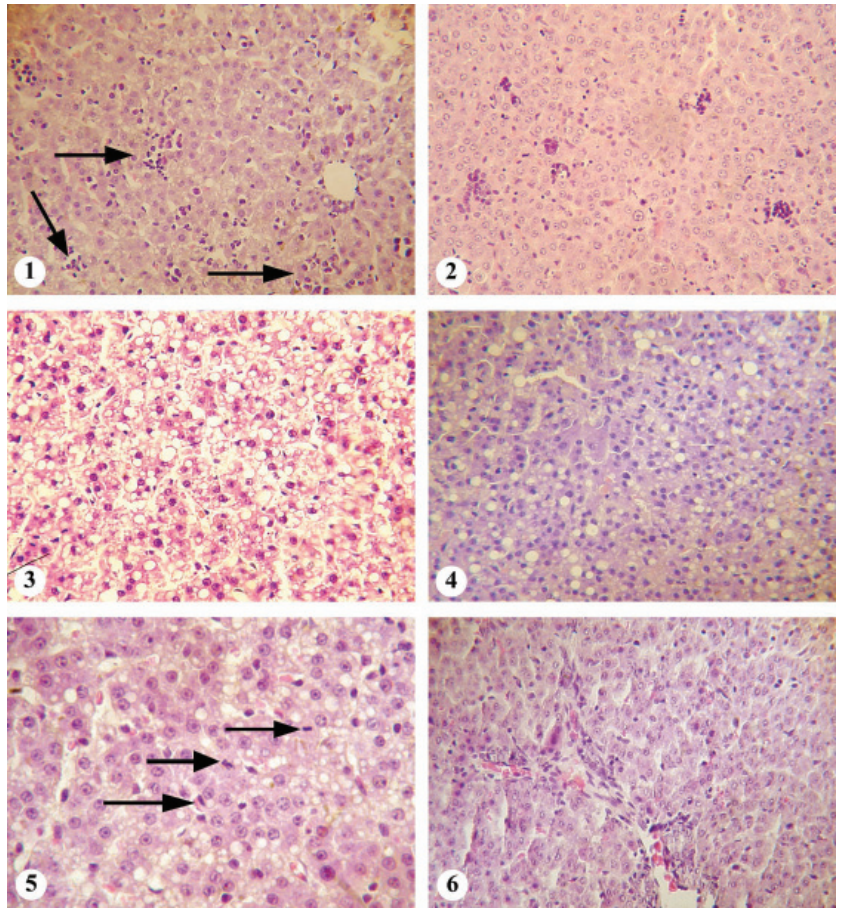

Figure 5 - Histological findings of control newborn rat livers and remnant livers on the days following PH. 1 is the control; 2, 3, 4, 5 and 6 correspond to $1,2,3,4$ and 7 days after $\mathrm{PH}$, respectively (original magnification X 150 and 300). 1- Typical sinusoidal architecture, with several extramedullary hematopoietic foci (arrows). 2- Enlargement of hepatocyte nuclei with prominent nucleoli. 3- Intense macrovesicular steatosis. 4- Decrease in steatosis. 5- Mitotic figures in hepatocytes (arrows) and marked reduction of steatosis. 6- Histological aspect similar to control.

Liver parenchyma of weaning control animals displayed similar architecture to the newborn animals, but no hematopoetic foci were evident (Figure 6-1). On the first day after $\mathrm{PH}$, their nuclei became vesicular with prominent nucleoli, and different phases of hepatocyte mitosis were observed throughout the lobule. On the second day, an increased number of hepatocyte mitoses were observed, although no steatosis was detected. Apoptotic bodies were rarely observed. From the third day, the number of hepatocyte mitoses decreased and could not be detected on the seventh day, when parenchymal architecture was completely recovered (Fig. 6- 2 to 6).

Figures 7 and 8 highlight hepatocyte mitosis and an apoptotic body, respectively.

\section{DISCUSSION}

Despite the widespread use of in vivo models for biological phenomena studies, research on growing animals is rare. Models of pancreatic beta-cells regeneration in
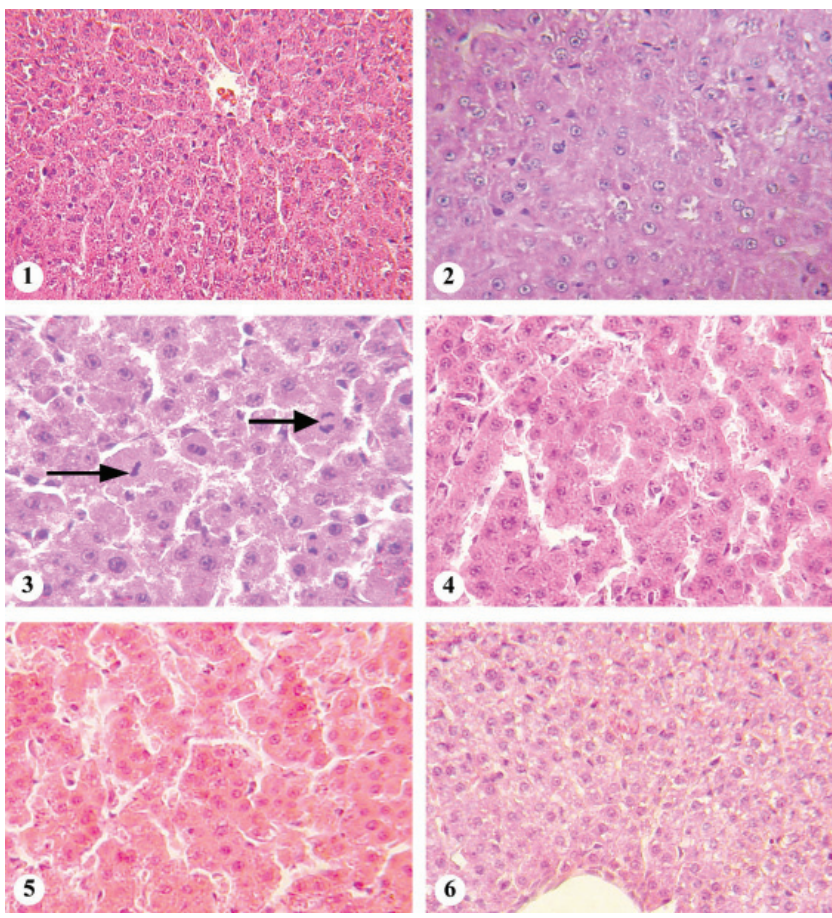

Figure 6 - Histological findings of the liver of control weaning rat and remnant liver on days following PH. 1 is the control; $2,3,4,5$ and 6 correspond to 1, 2, 3, 4 and 7 days after $\mathrm{PH}$ (original magnification X 150 and 300). 1- Typical sinusoidal architecture. 2- Enlargement of hepatocyte nuclei with prominent nucleoli. 3- Mitotic figures in different phases (arrows) and no steatosis. Since the third day (4), parenchimal architecture becomes histologically similar to control (5 and 6).

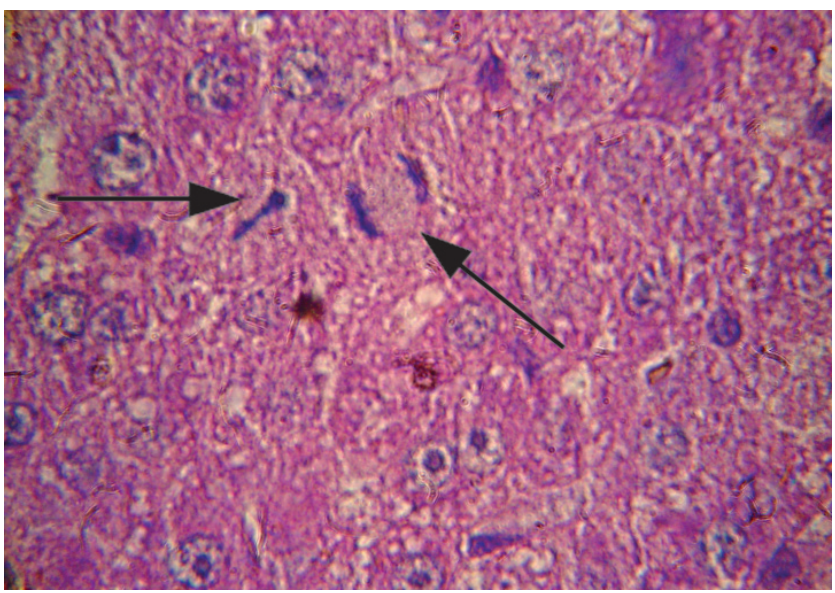

Figure 7 - Photomicrograph of a weaning rat liver on the second day after $\mathrm{PH}$, with hepatocyte mitoses (arrow) (original magnification X 1500, under oil immersion).

neonatal streptozotocin-treated rats ${ }^{12}$ and wound-healing studies in genetically modified newborn rats are rare examples of studies in growing animals. ${ }^{13}$

Anesthesia, respiratory depression, and frail and small sized organs, together with maternal cannibalism, represent severe difficulties in experiments with growing animals, especially newborns. Indeed, there was a significantly 


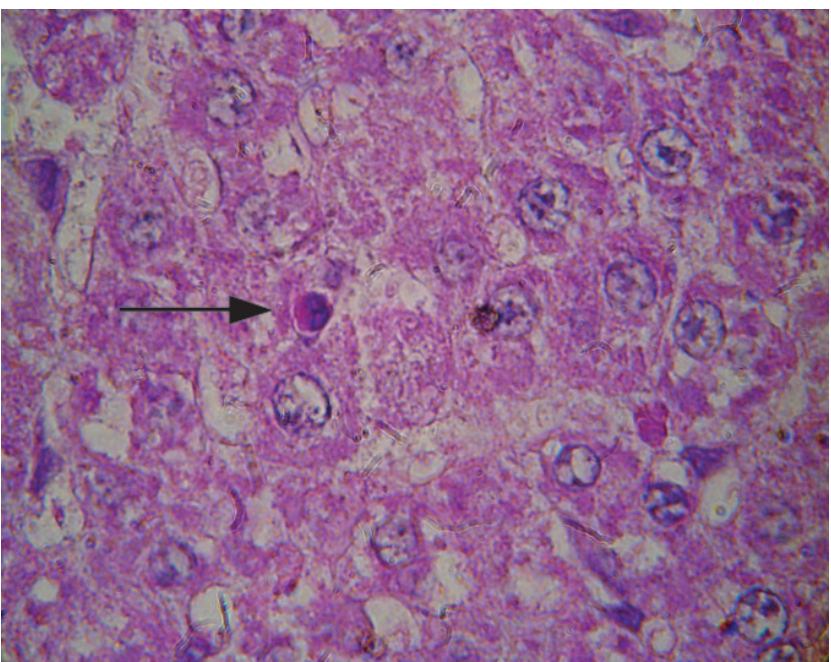

Figure 8 - Photomicrograph of a weaning rat liver on the first day after PH, with an apoptotic body. See eosinophilic cytoplasm and dense nuclear fragments arrow (original magnification X 1500, under oil immersion).

higher mortality rate in newborn animals relative to weaning animals $(\mathrm{P}=0.003)$. Despite this fact, the creation of a newborn experimental model of hepatectomy and liver regeneration in rats (age 5-7 days) is important because these animals correspond to children weighing less than 5 $\mathrm{kg}$. With the development and refinement of surgical techniques and microsurgical anastomoses, a series of liver transplants in such babies have been described and performed in centers throughout the world. ${ }^{14,15}$ As a result, we conclude that learning about hepatic regeneration and remodeling mechanisms in newborns is of significant importance.

The weaning model resembles infants who have been submitted to partial liver transplantation at age 1-year, secondary to biliary atresia, which is the most common indication for hepatic transplantation in the pediatric population. ${ }^{11}$ Patients without biliary drainage after Kasai's procedure and non-operated children develop rapidly progressive cirrhosis, which necessitates liver transplantation within 6 to 18 months. ${ }^{16}$

Because it is technically difficult to create experimental models of liver transplantation using small growing animals, we developed the present experimental models to study molecular histomorphological and immunohistochemical mechanisms of liver regeneration. Although these models do not include liver transplantation, data obtained can be transposed to all conditions of liver parenchyma regeneration or liver size remodeling.
The daily assessment of remnant liver weight showed a gradual increase in hepatic mass from the first post-operative day until complete recovery by the seventh day. These results are similar to descriptions in adult rat models. ${ }^{4,5}$ However, newborn animals exhibited a sharp increase in liver weight from the first to the second day after hepatectomy. Histological examination revealed intense fat accumulation in the liver parenchyma, resulting in weight gain. In addition, the increased number of hepatocyte mitoses observed after the third day reflects the high proliferative activity of liver cells during this phase.

During the early period of regeneration, the liver accumulates fat. ${ }^{17}$ Neither the mechanisms responsible for nor the functional significance of transient steatosis have been determined. In the current investigation, we observed that steatosis was more prominent in the newborn rat as compared to weaning rat livers. Interestingly, there are no descriptions of such fat accumulation in adult rat models of hepatectomy and liver regeneration. It is likely that the immaturity of the enzymatic systems of newborn hepatocytes promotes insufficient fat metabolism due to the increased metabolic demand of the remnant liver parenchyma.

Serial pathological analyses revealed that hepatocyte mitoses were more evident and earlier in the weaning animals than those observed in the newborn animals. Therefore, the initial liver weight gain in weaning animals was due to cellular proliferation, not steatosis; likewise, the proliferative activity of newborn hepatocytes, although slower, resulted in complete recovery of liver mass by the seventh day.

\section{CONCLUSIONS}

The present investigation demonstrates that suckling and weaning rat models of partial hepatectomy are feasible and can be used to study liver regeneration. Serial weight and histological analysis revealed that, although similar, the process of hepatic regeneration in growing animals is different from adult animals, which highlights the need for a model to study this process in young, growing organisms. The models created and standardized in the present research will enable further elucidation of the mechanisms involved in liver regeneration, as well as the development of therapeutic interventions in this complex phenomenon.

\section{ACKNOWLEDGMENT}

Grants from FAPESP 07/01333-2. 
Tannuri ACA, Tannuri U, Coelho MC, dos Santos NA e Mello ES. Modelos experimentais de hepatectomia e regeneração hepática em ratos recém-nascidos e recémdesmamados. Clinics. 2007;62(6):757-62.

OBJETIVOS: A regeneração hepática é um processo complexo não completamente elucidado. O modelo mais utilizado para o estudo desse fenômeno é a hepatectomia a $70 \%$ em ratos adultos. Não há trabalhos utilizando modelos em animais em crescimento. Desta forma, os objetivos deste estudo foram: 1. padronizar dois modelos de hepatectomia parcial e regeneração hepática utilizando ratos recém-nascidos e recém-desmamados; 2. estudar a evolução do peso do fígado remanescente e as alterações histológicas do parênquima hepático nos dias subseqüentes à hepatectomia parcial.

MÉTODOS: Cinqüenta ratos recém-nascidos e quarenta e quatro ratos recém-desmamados foram submetidos à hepatectomia a 70\%. Após laparotomia mediana, foi realizada compressão bilateral no abdome superior do animal, levando à exteriorização dos lobos hepáticos direito medial, esquerdo medial e esquerdo lateral, que foram ligados na base e ressecados em bloco. Os animais foram sacrificados logo após a hepatectomia e no $1^{\mathrm{o}}, 2^{\mathrm{o}}, 3^{\circ}, 4^{\mathrm{o}}$, e $7^{\circ}$ dias após a cirurgia. $\mathrm{O}$ peso corpóreo e do fígado foram determinados, e o parênquima hepático submetido à análise histológica.

RESULTADOS: Os índices de mortalidade dos animais recém-nascidos e recém-desmamados foram $30 \%$ e $0 \%$ respectivamente. Em ambos os grupos, houve uma diminuição significativa na massa hepática logo após a hepatectomia, com recuperação completa no sétimo dia de pós-operatório. $\mathrm{O}$ parênquima hepático dos animais recémnascidos apresentou acentuada esteatose no segundo dia. $\mathrm{O}$ fígado do animal recém-desmamado exibiu figuras mitóticas mais precoces e mais numerosas que o do recém-nascido.

CONCLUSÕES: Os modelos de hepatectomia parcial em ratos recém-nascidos e recém-desmamados são factíveis e podem ser usados para estudos da regeneração hepática. Embora semelhante, o processo de regeneração hepática em animais em crescimento não é igual ao do animal adulto.

UNITERMOS: Regeneração hepática. Modelos animais. Hepatectomia. Animais recém-nascidos. Rato.

\section{REFERENCES}

1. Court FG, Wemyss-Holden SA, Dennison AR, Maddern GJ. The mystery of liver regeneration. Br J Surg. 2002;89:1089-1095.

2. Palmes D, Spiegel HU. Animal models of liver regeneration. Biomaterials. 2004;25:1601-1611.

3. LaBrecque D. Liver regeneration: a picture emerges from the puzzle. Am J Gastroenterol. 1994;89:886-896.

4. Higgins GM, Anderson RM. Experimental pathology of the liver Restoration of the liver of the white rat following partial surgical removal. Arch Pathol. 1931;12:186-202.

5. Fausto N. Liver Regeneration. J Hepatol. 2000;32(1 Suppl):19-31.

6. Bucher NLR, Farmer SR. Liver regeneration following partial hepatectomy: genes and metabolism. In : strain AJ, Diehl AM, editors. Liver Growth and Repair. London: Chapman \& Hall; 1998: 3-27.

7. Michalopoulos GK, DeFrances MC. Liver Regeneration. Science. 1997; 276:60-66

8. Biondo-Simões MLP, Matias JEF, Montibeller GR, Siqueira LCD, Nunes ES, Grassi CA. Efeitos do envelhecimento na regeneração hepática em ratos. Acta Cir Bras. 2006;21:197-202.

9. Varela-Fascinetto G, Dávila-Perez R, Hernández-Plata A, CastañedaMartínez P, Fuentes-Garcia V, Nieto-Zermeño J. Pediatric Liver Transplantation. Rev Invest Clin. 2005;57:273-282.
10. Otte JB. History of pediatric liver transplantation. Where are we coming from? Where do we stand? Pediatr Transplant. 2002;6:378-387.

11. Tannuri U, Velhote MC, Santos MM, Gibelli NE, Ayoub AA, MaksoudFilho JG, Silva MM, Pinho ML, Miyatani HT, Maksoud JG. Pediatric liver transplantation: fourteen years of experience at the children institute in Sao Paulo, Brazil. Transplant Proc. 2004:36:941-942.

12. Li L, Yi Z, Seno M, Kojima I. Activin A and betacellulin: effect on regeneration of pancreatic beta-cells in neonatal streptozotocin-treated rats. Diabetes. 2004;53:608-615.

13. Liu W, Mehrara BJ, Chin GS, Hsu M, Peled Z, Longaker MT. The use of newborn rats and an adenoviral gene delivery vector as a model system for wound-healing research. Ann Plast Surg. 2000;44:543-551.

14. Vanatta JM, Esquivel CO. Status of liver transplantation in infants < 5kg. Pediatric Transplantation. 2007;11:5-9.

15. Mekeel KL, Langham Jr MR, Gonzalez-Peralta RP, Hemming AW. Liver transplantation in very small infants. Pediatric Transplantation. 2007;11:66-72.

16. Silva MM, Maksoud JG. Atresia das vias biliares. In: Maksoud JG. Cirurgia Pediátrica. 2a ed. Rio de Janeiro: Revinter; 2003. p.904-922

17. Kumar V, Abbas AK, Fausto N: Robbins and Cotran Pathologic Basis of Disease. Philadelphia, Elsevier Saunders, 2004 